\begin{tabular}{|c|l|}
\hline Title & $\begin{array}{l}\text { Effect of metal cations on corrosion behavior and surface film structure of the A 3003 al uminum alloy in model tap } \\
\text { waters }\end{array}$ \\
\hline Author(s) & Otani, K.; Sakairi, Masatoshi; Sasaki, R.; Kaneko, A.; Seki, Y.; Nagasawa, D. \\
\hline Citation & $\begin{array}{l}\text { Journal of solid state electrochemistry, 18(2), 325-332 } \\
\text { https:/doi.org/10.1007/310008_013_2260-7 }\end{array}$ \\
\hline Issue Date & 201402 \\
\hline Doc URL & http://hdl.handle.net/2115/57822 \\
\hline Rights & The final publication is available at link.springer.com \\
\hline Type & article (author version) \\
\hline File Information & JSEL_18_325_2014.pdf \\
\hline
\end{tabular}

Instructions for use 


\title{
Effect of metal cations on corrosion behavior and surface film structure of the A3003 aluminum alloy in model tap waters
}

\author{
K. Otani ${ }^{1,2)}$, M. Sakairi ${ }^{1)}$, R. Sasaki ${ }^{1)}$, A. Kaneko ${ }^{3)}$, Y. Seki $^{3)}$ and D. Nagasawa ${ }^{3)}$ \\ 1) Graduate School of Engineering, Hokkaido University, Sapporo, Japan \\ ${ }^{2)}$ Presently; Saitama Plant, Toyo Seikan Kaisha, Ltd., Hiki-gun, Japan \\ ${ }^{3)}$ Nikkei Research \& Development Center, Nippon Light Metal Co. Ltd., Shizuoka, Japan
}

\begin{abstract}
The effect of the metal cations, $\mathrm{Na}^{+}, \mathrm{K}^{+}, \mathrm{Ca}^{2+}, \mathrm{Mg}^{2+}, \mathrm{Zn}^{2+}$, and $\mathrm{Ni}^{2+}$, on the oxide film structure and morphology changes during long term immersion corrosion tests of aluminum alloy (A3003) in model tap waters was investigated by X-ray photoelectron spectroscopy (XPS), and scanning electron microscopy. The effect of the metal cations on the corrosion behavior was also investigated with mass change and electrochemical tests. The hardness of the metal cations, $X$, based on the Hard and Soft Acids and Bases (HSAB) concept was applied to explain the effect of metal cations on the passive oxide film structure and corrosion resistance. The mass change rate and corrosion current density decreased with increasing metal cation hardness. The XPS results showed that hard metal cations like $\mathrm{Zn}^{2+}$ and $\mathrm{Ni}^{2+}$ were incorporated in the oxide films, while the four soft metal cations were not incorporated in the oxide films. The results are in good agreement with those which could be expected from the HSAB hardness of the metal cations.
\end{abstract}

Key words; metal cation, aluminum alloy, tap water, corrosion, passive film

Corresponding author.

e-mail address: msakairi@eng.hokudai.ac.jp (M. Sakairi) 


\section{Introduction}

Aluminum alloys are widely used because of the high strength/weight ratios and they show good corrosion resistance in most environments. The good corrosion resistance is explained by protective oxide films, passive films, covering the aluminum alloy surface. Generally, the corrosion rate of aluminum alloys depends on the concentration of chloride ions, and it is considered that only little corrosion of aluminum alloys occurs in very dilute chloride solutions such as tap waters. There are only few studies focused on corrosion of aluminum and aluminum alloys in tap water [1-9].

The A3003 is well known to have good corrosion resistance, specific strength, weldability, and workability. Therefore, A3003 is commonly used in environments such as with tap waters [10-14]. However, corrosion of A3003 sometimes does occur in tap water, and this causes leakage of water when the alloy is used in containers and water supply tubes. Tap water contains very low concentrations of anions and metal cations. It is considered that corrosion is affected by not only chloride ions but also metal cations, which are in the tap water. However, there are only few papers that have investigated the effect of metal cations on the corrosion behavior of A3003 and other aluminum alloys. Some research on the effect of metal cations on corrosion behavior of steels have been reported, and here corrosion behavior changes with the kind of the metal cations in solutions [15-17]. Some of the authors also investigated the effect of metal cations on the corrosion behavior of A3003 in model tap waters [18-22], and it was found that the corrosion behavior of A3003 strongly depends on the kinds of metal cations in the environment.

In recent research, it was reported that the corrosion rate of stainless steels is suppressed with increases in the hardness of the metal cations in dilute chloride solutions, and that hard metal cations become incorporated into the passive film [23]. However, there is no analytical data of the incorporation of hard metal cations in passive films in that report.

The metal cation hardness is based on the hard and soft acid and base, HSAB, concept. According to the Lewis rule concerning acid and bases, cations and anions act as acids and bases, respectively. Further, acids and bases are classified into hard and soft according to the HSAB concept. The hardness of metal cations can be expressed as follows[23, 24],

$$
X=\left[X_{\mathrm{M}}^{0}+\left(\sum I_{\mathrm{n}}\right)^{1 / 2}\right]^{2} / 10
$$

where $X_{\mathrm{M}}^{0}$ is the electronegativity of the metal atom, and $I_{\mathrm{n}}(\mathrm{eV})$ is the ionization potential from the neutral metal atom to the given oxidized state, $n$. Zhang et al. investigated the inhibiting effect of metal cations on the Intergranular Stress Corrosion Cracking (IGSCC) behavior of a sensitized Type 304 stainless steel, and discussed the IGSCC inhibition mechanism due to the metal cations on the basis of the passive film model combined with the HSAB concept [23]. Hard metal cations change the characteristics of passive films to decrease the susceptibility of IGSCC. 
With X-ray photoelectron spectroscopy, XPS, it is possible to determine the presence of incorporated metal cations in passive films or corrosion products on alloys [25-27]. This technique can also determine the chemical state of the elements in the films. Some of the authors reported that hard metal cations were present in the passive films formed on aluminum and its alloys after immersion in model tap water by AES and XPS analysis [28]. However, the effect of the presence of metal cations in passive films or in the corroding solution on long term immersion corrosion behavior and polarization behavior of A3003 in model tap water is not fully elucidated. The purpose of the present study is to clarify the influences of metal cations in model tap waters on the corrosion mechanisms of A3003 by metal cation hardness theory and XPS surface analysis.

\section{Experimental}

\subsection{Specimens}

Specimens of Al A3003 sheets with thickness $1.2 \mathrm{~mm}$ were used as specimens, $7 \times 7 \mathrm{~mm}$ for immersion corrosion tests and $20 \times 30 \mathrm{~mm}$ for polarization tests. Table 1 shows chemical composition of A3003. Before the tests, specimens were chemically etched in $0.1 \mathrm{kmol} \mathrm{m}^{-3} \mathrm{NaOH}$ solutions and then cleaned in ethanol and in doubly distilled water in an ultrasonic bath. After cleaning, the specimen of polarization tests was sealed by silicone resin, to ensure that a $15 \mathrm{~mm}$ by $15 \mathrm{~mm}$ area on one side was in contact with the electrolyte solution.

\subsection{Model tap waters}

The model tap waters (solutions in the following) used was $0.5 \mathrm{kmol} \mathrm{m}^{-3} \mathrm{H}_{3} \mathrm{BO}_{3}-0.05 \mathrm{kmol} \mathrm{m}^{-3}$ $\mathrm{Na}_{2} \mathrm{~B}_{4} \mathrm{O}_{7}$ (borate) each with one of six different salts: $1 \mathrm{~mol} \mathrm{~m}^{-3} \mathrm{KCl}, 1 \mathrm{~mol} \mathrm{~m}^{-3} \mathrm{NaCl}, 0.5 \mathrm{~mol} \mathrm{~m}^{-3} \mathrm{CaCl}_{2}$, $0.5 \mathrm{~mol} \mathrm{~m}^{-3} \mathrm{MgCl}_{2}, 0.5 \mathrm{~mol} \mathrm{~m}^{-3} \mathrm{ZnCl}_{2}$, and $0.5 \mathrm{~mol} \mathrm{~m}^{-3} \mathrm{NiCl}_{2}$. The corrosion behavior of aluminum alloys strongly depend on the $\mathrm{pH}$ of the solutions, and the $\mathrm{pH}$ of tap water is close to neutral. The total ion concentration of borate here is higher than usual tap waters, however, to avoid a $\mathrm{pH}$ effect on the corrosion behavior, borate was selected as the basic solution of the model tap waters in this study. The concentration of the chloride ions in model tap waters was $1 \mathrm{~mol} \mathrm{~m}^{-3}$, similar to that of usual tap water. The total ion concentration of the model tap water is higher than that of usual tap water, however, with the similar $\mathrm{pH}$ and chloride ion concentration, the model tap waters used in this study can be considered similar to usual tap water. All chemicals were commercially available special grade and obtained from Kanto Chemical Co. Ltd. The main metal cations contained in the borate solution is $\mathrm{Na}^{+}$, and with the different salts it is possible to determine the effect of the minor and/or added metal cations $\left[\mathrm{K}^{+}, \mathrm{Ca}^{2+}\right.$, $\left.\mathrm{Mg}^{2+}, \mathrm{Ni}^{2+}, \mathrm{Zn}^{2+}\right]$. The hardness of the metal cations, $X$, calculated by equation (1) increases in the order $\mathrm{K}^{+}<\mathrm{Na}^{+}<\mathrm{Ca}^{2+}<\mathrm{Mg}^{2+}<\mathrm{Zn}^{2+}<\mathrm{Ni}^{2+}$. The $\mathrm{Na}^{+}$added solution was used as the reference solution for the corrosion behavior of the other metal cation containing solutions.

\subsection{Corrosion tests}




\subsubsection{Immersion corrosion tests}

Specimens were dipped in the still (unagitated) solutions for $2.59 \mathrm{Ms}$ (30 days) at $323 \mathrm{~K}$. The solutions were changed every 864 ks (10 days), and the mass of the specimens were measured when the solutions were changed. Before mass measurements, specimens were rinsed with doubly distilled water and then dried well in the desiccator, and the measurement was carried out twice for one specimen at different desiccation time to avoid effect of adsorbed water. The solution temperature was selected in consideration of potential applications of the alloy for home heating systems and to accelerate the corrosion rate. Immersed specimen surfaces were observed by a scanning electron microscope (SEM, JEOL Ltd., JSL6510-LA). The surface films were analyzed by an X-ray photoelectron spectroscope (XPS, JEOL Ltd., JPS-9200) using an Mg K $\alpha$ X-ray source (1253.6 eV), and the area analyzed by XPS was $3 \times$ $3 \mathrm{~mm}$ in all the experiments, with no Ar ion sputtering.

\subsubsection{Polarization curves}

The potentiodynamic polarization tests were performed in a standard three-electrode cell. Specimens were dipped in the still (unagitated) solutions at $298 \mathrm{~K}$, then polarized from negative potential to positive directions at scanning rate of $1.0 \mathrm{mVs}^{-1}$. The counter electrode was a $18 \mathrm{~cm}^{2} \mathrm{Pt}$ plate and the $\mathrm{Ag} / \mathrm{AgCl}$ saturated $\mathrm{KCl}$ electrode was used as the reference electrode.

\section{Results and Discussion}

\subsection{Immersion corrosion tests}

The mass change, $\Delta \mathrm{M}$, of the A3003 during the immersion corrosion tests in borate solution with 1 $\mathrm{mol} \mathrm{m}{ }^{-3} \mathrm{NaCl}, 1 \mathrm{molm}^{-3} \mathrm{KCl}, 0.5 \mathrm{~mol} \mathrm{~m}^{-3} \mathrm{CaCl}_{2}, 0.5 \mathrm{~mol} \mathrm{~m}^{-3} \mathrm{MgCl}_{2}, 0.5 \mathrm{~mol} \mathrm{~m}^{-3} \mathrm{ZnCl}_{2}$, or $0.5 \mathrm{~mol} \mathrm{~m}^{-3}$ $\mathrm{NiCl}_{2}$ at $323 \mathrm{~K}$ is shown in Figure 1. In the solutions, containing soft metal cations, $\mathrm{Na}^{+}, \mathrm{K}^{+}, \mathrm{Mg}^{2+}$, and $\mathrm{Ca}^{2+}, \Delta M$ decreases with the immersion time. The specimen immersed in the $\mathrm{Ca}^{2+}$ containing solution, $\Delta M$ is smaller than other three soft metal cations. In the solutions containing hard metal cations, $\mathrm{Ni}^{2+}$ and $\mathrm{Zn}^{2+}, \Delta M$ changes little with immersion time.

The absolute value of $\Delta M_{\mathrm{t}}$ after immersion in the solutions (model tap waters) for 2.59 Ms (30 days) in Figure 1 as a function of the hardness of the metal cation, $X$, is shown in Figure 2. As Figure 2 shows the absolute value of $\Delta M_{\mathrm{t}}$ decreases with increasing $\mathrm{X}$, except for $\mathrm{Mg}$. However, the metal cation hardness order detailed in 2.2 agrees with the changes in the $\Delta M_{\mathrm{t}}$ values and may be seen to explain the mass changes of the A3003. These results suggest that the hardness of the metal cations plays important role in the corrosion rates of A3003 in the model tap waters.

Surface images of A3003 after the immersion corrosion tests in borate solution with $1 \mathrm{~mol} \mathrm{~m}^{-3} \mathrm{NaCl}$, $1 \mathrm{~mol} \mathrm{~m} \mathrm{KCl}^{-3} \mathrm{~K}, 5 \mathrm{~mol} \mathrm{~m}^{-3} \mathrm{CaCl}_{2}, 0.5 \mathrm{~mol} \mathrm{~m}^{-3} \mathrm{MgCl}_{2}, 0.5 \mathrm{~mol} \mathrm{~m}^{-3} \mathrm{ZnCl}_{2}$, and $0.5 \mathrm{~mol} \mathrm{~m}^{-3} \mathrm{NiCl}_{2}$ are shown in Figure 3. Left to right, the images are in the order of the hardness of the metal cations. It is clearly seen that pits of about $10 \mu \mathrm{m}$ in diameter appear on the specimen surfaces immersed in $\mathrm{Na}^{+}$and 
$\mathrm{K}^{+}$containing solutions, and the results here show good agreement with the changes in $\Delta M$ in Figure 1. The size and number of pits decrease with increasing $X$, and there are only few corrosion pits on specimens immersed in $\mathrm{Ni}^{2+}$ containing solutions. The specimen surface after immersion in $\mathrm{Zn}^{2+}$ containing solutions also show few corrosion pits, and it displays the scratch lines, which formed during the rolling. This result indicates that the surface here may be covered with relatively thick corrosion products. The surface morphology and the results of the immersion tests show good correlation with the cation hardness.

\subsection{Polarization results}

Figure 4 shows the anodic and cathodic polarization curves of A3003 in borate solutions with $1 \mathrm{~mol}$ $\mathrm{m}^{-3} \mathrm{NaCl}, 1 \mathrm{~mol} \mathrm{~m}^{-3} \mathrm{KCl}, 0.5 \mathrm{~mol} \mathrm{~m}^{-3} \mathrm{CaCl}_{2}, 0.5 \mathrm{~mol} \mathrm{~m}^{-3} \mathrm{MgCl}_{2}, 0.5 \mathrm{~mol} \mathrm{~m}^{-3} \mathrm{NiCl}_{2}$, and $0.5 \mathrm{~mol} \mathrm{~m}^{-3}$ $\mathrm{ZnCl}_{2}$ at $298 \mathrm{~K}$. The rest potential increases with increasing $X$ (metal cation hardness), and the current changes with potential may be categorized into three groups: 1) $\mathrm{In} \mathrm{Na}^{+}$and $\mathrm{K}^{+}$containing solutions, the current increased sharply with increasing potential, when the potential increased from the rest potential and in the positive direction, it then reaches a steady value. The steady potential regions are related to constant growth of the passive films. 2) In $\mathrm{Mg}^{2+}$ and $\mathrm{Ca}^{2+}$ containing solutions, the current increases slowly before reaching a steady value above potentials higher than 0.2 V. 3) $\mathrm{In} \mathrm{Ni}^{2+}$ and $\mathrm{Zn}^{2+}$, the current increases sharply with potential increases from the rest potential, reaches a peak and then decreases to settle at a steady value; at potentials higher than $0.2 \mathrm{~V}$, the current resumed increasing to reach a higher steady value.

The corrosion potential and corrosion current were calculated by the Tafel extrapolation method from the polarization curves in Figure 4. The corrosion potential as a function of the metal cation hardness, $X$ is shown in Figure 5 a), and the corrosion current as a function of $X$ is shown in Figure $5 \mathrm{~b}$ ). The corrosion potential increases while the corrosion current density decreases with $X$. These results suggest that the corrosion rate of A3003 observed by the polarization curves is suppressed by the harder metal cations. The results of the polarization measurements show a good correlation with the results of the immersion corrosion tests.

\subsection{XPS analysis}

The results of the immersion corrosion tests and polarization measurements, suggest that the protectiveness of passive film may be affected by the metal cations in the solution. To better understand the effect of metal cations on the surface film structure, the specimen surfaces after the immersion tests were investigated by XPS. Figure 6 shows XPS narrow spectrums of each element after $2592 \mathrm{ks}$ (30 days) immersion in a) $1 \mathrm{~mol} \mathrm{~m}^{-3} \mathrm{NaCl}$, b) $1 \mathrm{~mol} \mathrm{~m}^{-3} \mathrm{KCl}$, c) $0.5 \mathrm{~mol} \mathrm{~m}^{-3} \mathrm{CaCl}_{2}$, d) $0.5 \mathrm{~mol} \mathrm{~m}^{-3} \mathrm{MgCl}_{2}$, e) $0.5 \mathrm{~mol} \mathrm{~m}^{-3} \mathrm{ZnCl}_{2}$, and f) $0.5 \mathrm{~mol} \mathrm{~m}^{-3} \mathrm{NiCl}_{2}$. There are no peaks of $\mathrm{Na} 1 \mathrm{~s}(1072 \mathrm{eV}), \mathrm{K} \mathrm{2p3/2}(294 \mathrm{eV})$ 
and $\mathrm{Mg} \mathrm{2p} \mathrm{(50} \mathrm{eV)} \mathrm{in} \mathrm{the} \mathrm{spectra.} \mathrm{From} \mathrm{these} \mathrm{results,} \mathrm{it} \mathrm{may} \mathrm{be} \mathrm{concluded} \mathrm{that} \mathrm{Na}, \mathrm{K}$, and $\mathrm{Mg}$ are not incorporated in the passive films. A weak peak of Ca 2 p (347 and $351 \mathrm{eV})$ is observed, suggesting that a small amount of $\mathrm{Ca}$ is incorporated in the passive film (Figure 6c). The spectra (Figure 6 e and $\mathrm{f}$ ) show peaks of $\mathrm{Ni} 2 \mathrm{p} 3 / 2(853 \mathrm{eV})$ and $\mathrm{Zn} \mathrm{2p3/2}(1022 \mathrm{eV})$, indicating that these hard metal cations are incorporated in the passive films. The peak of $\mathrm{Ni}$ is shifted a little to higher binding energies, indicating that $\mathrm{Ni}(\mathrm{OH})_{2}$ is present on the surface of the passive film [29].

Figure 7 shows XPS narrow spectrums of Al 2p and O 1s of specimens after immersed in each cation containing solutions. In every specimens, $\mathrm{Al}$ and $\mathrm{O}$ related peaks are clearly observed on every specimens. Therefore, main composition of surface films are $\mathrm{Al}_{2} \mathrm{O}_{3}$.

The XPS results indicate that hard metal cations suppress the corrosion of A3003 by incorporation of these metal cations in the passive film. Figure 8 is a schematic outline of the change in the oxide film structure as a result of immersion in hard metal cation containing solutions. The passive films formed on the specimens immersed in the solutions may consist of hydrated oxide and contain a large amount of bound water. The film may contain various forms of chemical bonds between metal ions and oxygen ions, such as $\mathrm{H}_{2} \mathrm{O}-\mathrm{Al}-\mathrm{OH}_{2}, \mathrm{HO}-\mathrm{Al}-\mathrm{OH}$, and $\mathrm{O}-\mathrm{Al}-\mathrm{O}$ (Figure 8(a)). According to the HSAB concept, the hard metal cation in the solution attracts the electron pair of oxygen atom in $\mathrm{H}_{2} \mathrm{O}$ or $\mathrm{OH}$ in the passive film, and hard metal cations in the solutions adsorb on oxygen atoms of $\mathrm{H}_{2} \mathrm{O}$ or $\mathrm{OH}$ in the passive film. The harder metal cation has stronger affinity to $\mathrm{OH}^{-}$, and that can be more easily replaced with the proton of $\mathrm{H}_{2} \mathrm{O}$ in the passive film [23]. Therefor, this adsorption of hard metal cations induces a loosening of the bonds between the oxygen atom and the protons of the $\mathrm{H}_{2} \mathrm{O}$ or the $\mathrm{OH}$, and causes de-protonation resulting in changes in the chemical bonds in the passive film (Figure $8(\mathrm{~b})$ ). The chemical bonds and the fewer protons at the outer surface of the passive film increase the protectiveness of the passive film, and reduces the corrosion rate and number of formed pits arising as a result of the immersion corrosion tests here.

A schematic outline of the corrosion and dissolution of aluminum with the added metal cations is shown in Figure 9. Chiba et al. investigated initial site for pitting corrosion of type 304 stainless steel by microelectrochemical system and reported that stable and meta-stable pitting events initiated at substrate and $\mathrm{MnS}$ boundaries [30]. By the SEM-EDS analysis (Figure 10), Mg-Si-Al related precipitates are observed, and in between these precipitates and the aluminum substrate there are areas where corrosion preferentially may occur, because no continuous oxide films may be formed, and aluminum may be preferentially dissolved here. As immersion time elapses in solutions with harder metal cations, $\mathrm{Zn}^{2+}$ and $\mathrm{Ni}^{2+}$, the harder metal cations have a stronger affinity to $\mathrm{OH}^{-}$and can be more easily replaced with the protons of $\mathrm{H}_{2} \mathrm{O}$ in the passive film covering metal. This may reduce the number of flaws in the passive film or it may increase the re-passivation rate. This would cause reduced dissolution of aluminum, especially at the boundary between precipitates and aluminum substrate. With soft metal cations, $\mathrm{K}^{+}$and 
$\mathrm{Na}^{+}$, no incorporation of the metal ions into the surface films during the immersion test no influence in the corrosion rate.

\section{Conclusion}

The effect of metal cations in model tap waters on surface oxide film structure and surface morphology changes were investigated by SEM, XPS, and electrochemical techniques, and the following conclusions may be drawn.

1) Corrosion pits of about $10 \mu \mathrm{m}$ in diameter were observed in solutions with soft metal cations such as $\mathrm{Na}^{+}$and $\mathrm{K}^{+}$. The corrosion behavior of A3003 in the model tap waters changed with metal cation hardness, $X$.

2) The corrosion potential increases and corrosion current decreases with increasing metal cation hardness.

3) Hard metal cations were observed by XPS in the oxide films formed on A3003 after immersion in the model tap waters containing these cations.

\section{Reference}

[1] Gough HJ, Sopwith DG (1932) Proceedings of the Royal Society of London, Series A: Mathematical, Physical and Engineering Sciences 135:392-411

[2] Pavlov SE, Soboleva VA (1957) Korroziya i Zashchita Metal 236-259

[3] Baba Y, Hagiwara M (1968) Sumitomo Keikinzoku Giho 9:208-217

[4] Gugliemi N, (1969) International Leichtmetalltag 5:39-43

[5] Uchiyama I, Ohno K, Sato E (1976) Aruminyumu Kenkyu Kaishi 103:67-68

[6] Reboul MC (1979) Corrosion 35:423-428

[7] Kanani N (1979) Aluminum 55:724-727

[8] Sakaida T, Ikeda H, Tanabe Z (1985) Sumitomo Keikinzoku Giho 26:221-229

[9] Furumata K, Suzuki T, Kobayashi J, Seri O (2001) Keikinzoku 51:242-245

[10] Uchiyama I, Sato E (1976) Boshoku Gijutsu 25:725-732

[11] Tohma K, Takeuchi Y (1979) Keikinzoku 29:498-504

[12] Gray RJ, Griess JC, Crouse RS, DeVan JH (1978) Microstructural Science 6:261-278

[13] Takabeya R (1986) Boshoku Gijutsu 35:623-632

[14] Xiao W, Hong S, Tang Z, Seal S, Taylor JS (2007) Corrosion Science 49:449-468

[15] Gormna GK (1998) Materials Chemistry and Physics 55:131-138

[16] Telegdi J, Shaglouf MM, Shaban A, Ka'rma'n FH, Betro'ti I, Mohai M, Ka'lma'n E (2001) Electrochimica Acta 46:3791-3799 
[17] Prosek T, Thierry D, Taxe'n C, Maixner J (2007) Corrosion Science 49:2676-2693

[18] Sakairi M, Shimoyama Y, Nagasawa D (2008) Corrosion Science and Technology 7:168-172

[19] Sakairi M, Kaneko A, Seki Y, Nagasawa D (2008) Proceedings of Eurocorro2008 2185

[20] Sakairi M, Kaneko A, Kikuchi T, Seki Y, Nagasawa D (2009) Proceedings of Eurocorr2009 NO. SS $17-0-7947$

[21] Otani K, Sakairi M, Kikuchi T, Kaneko A (2010) Zairyo-to-Kankyo 59:330-331

[22] Sakairi M, Kaneko A, Otani K, Seki Y, Nagasawa D (2011) Proceedings of 18th International Corrosion Congress 10:533 (10 pages)

[23] Zhang S, Shibata T, Haruna T (2005) Corrosion Science 47:1049-1061

[24] Misono M, Ochiai E, Saito Y, Yoneda Y (1967), Journal of Inorganic and Nuclear Chemistry 29:2685-2691

[25] Duret-Thual C, Costa D, Yang WP, Marcus P (1997) Corrosion Science 39:913-933

[26] Reier T, Simson A, Schultze JW (1998) Electrochimica Acta 43:149-158

[27] Hryniewicz T, Rok-osz K, Rok-ick-I R (2008) Corrosion Science 50:2676-2681

[28] Sakairi M, Otani Y, Kaneko A, Seki Y, Nagasawa D (2013) Analysis of chemical compositions and morphology of surface films formed on 3003 aluminum alloy by immersion in different cation containing model tap waters. Surface and Interface Analysis special Issue article, DOI 10.1002/sia.5256

[29] Li-yuan Q, Jian-she L, Qing J (2010) Transactions of Nonferrous Metals Society of China 20:82-89

[30] Chiba A, Muto I, Sugawara Y, Hara N (2012) Journal of the Electrochemical Society 159:C341C350 


\section{Captions}

Table 1 Chemical composition of A3003 (mass\%).

Figure 1 Change of mass per unit area of A3003 specimen surface as a function of immersion time in the model tap waters with various cations.

Figure 2 Changes in total change of mass per unit area of A3003 specimen surface as a function of the hardness of the added metal cations.

Figure 3 SEM images of A3003 after the immersion corrosion test for $2.59 \mathrm{Ms}$ (30 days) in borate solution with various cations at $323 \mathrm{~K}$.

Figure 4 Potentiodynamic polarization curves of A3003 in borate solution with various cations at $298 \mathrm{~K}$.

Figure 5 (a) corrosion potentials and (b) corrosion currents of A3003 as a function of the hardness of the added metal cation, $X$.

Figure 6 XPS narrow spectra for the elements of the specimens in Figure 3.

Figure 7 XPS narrow spectra for $\mathrm{Al}$ and $\mathrm{O}$ of the specimen in Figure 3.

Figure 8 Schematic representation of the oxide film structure changes after immersion in hard metal cation containing solutions.

Figure 9 Schematic representation of corrosion resistance changes with incorporation of metal cations.

Figure 10 SEM image and EDS analysis results of the sample surface before immersion test. 
Table 1 Chemical composition of A3003 (mass\%)

\begin{tabular}{cccccccc}
\hline $\mathrm{Cu}$ & $\mathrm{Si}$ & $\mathrm{Fe}$ & $\mathrm{Mn}$ & $\mathrm{Mg}$ & $\mathrm{Zn}$ & $\mathrm{Ti}$ & $\mathrm{Al}$ \\
\hline 0.11 & 0.36 & 0.55 & 1.08 & $<0.01$ & 0.01 & 0.03 & bal. \\
\hline
\end{tabular}




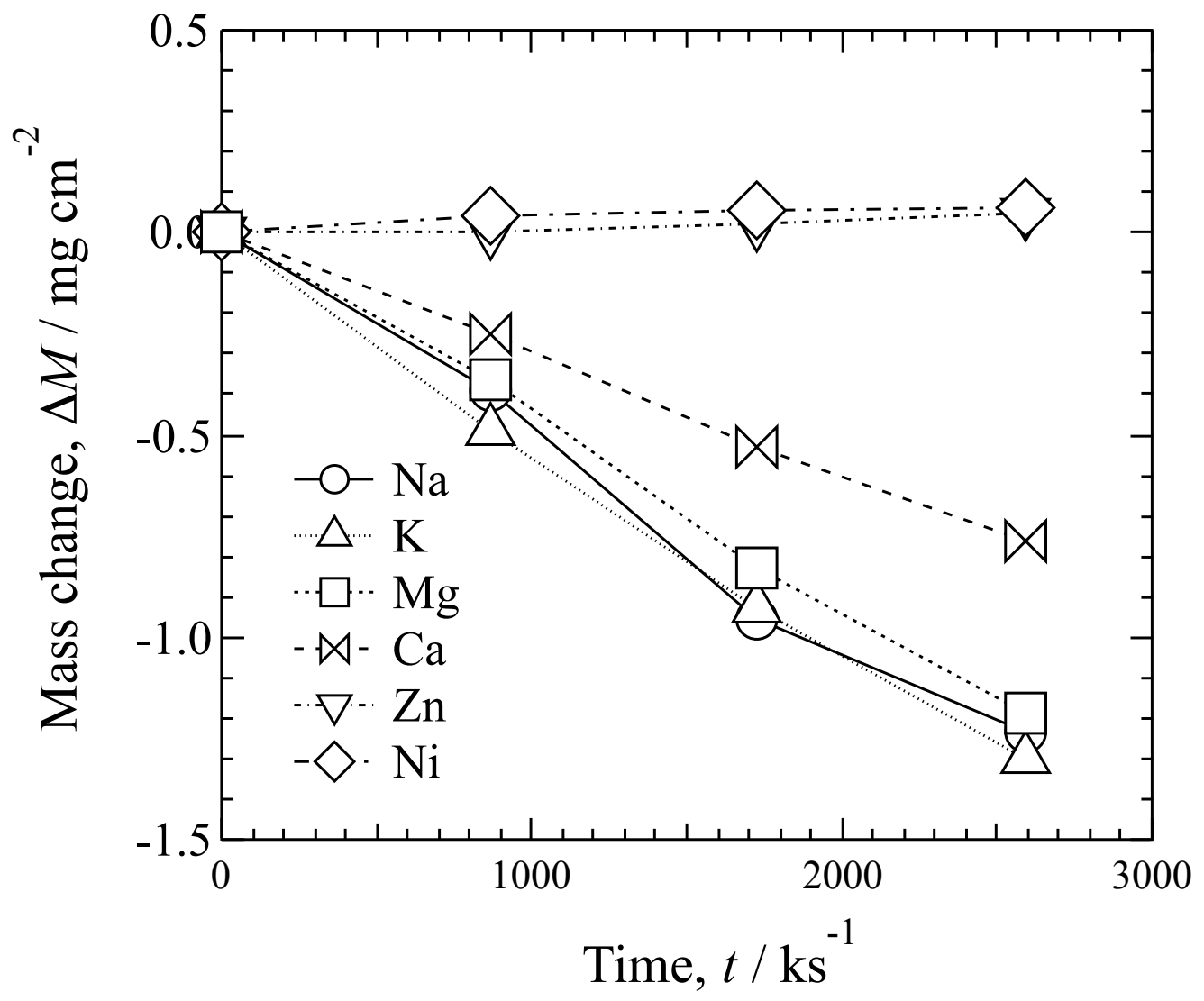

Figure 1 


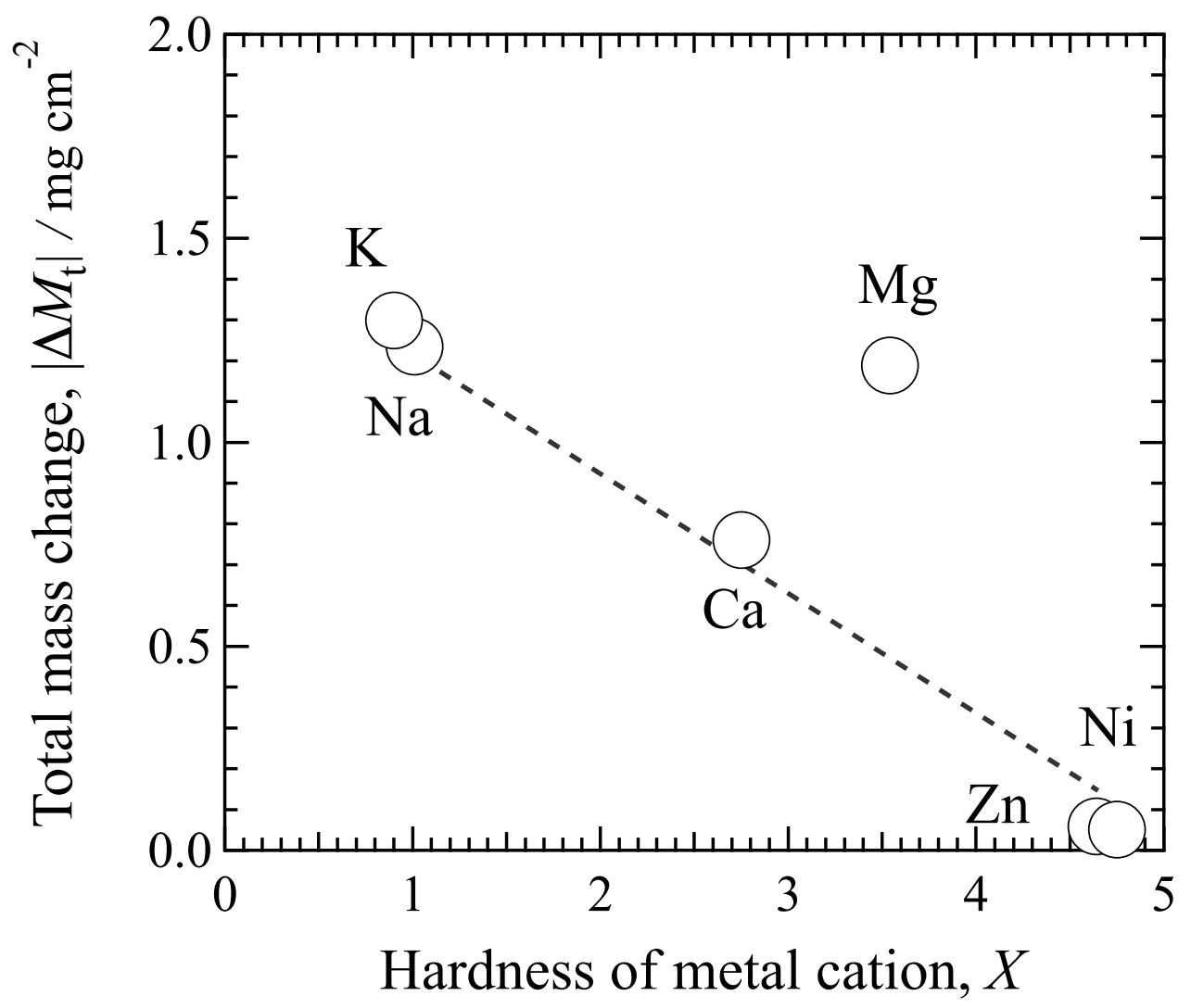

Figure 2 


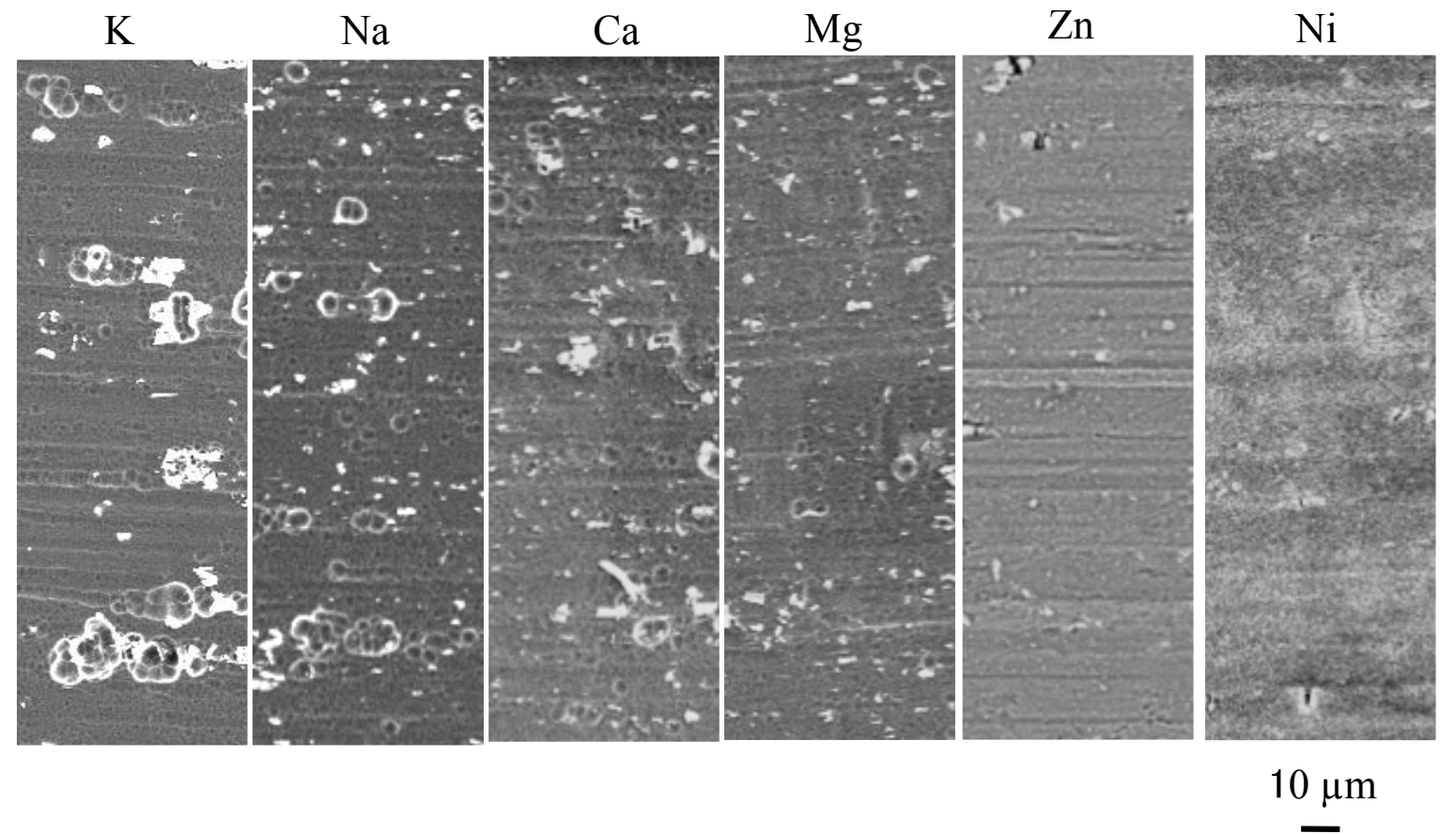

Figure 3 


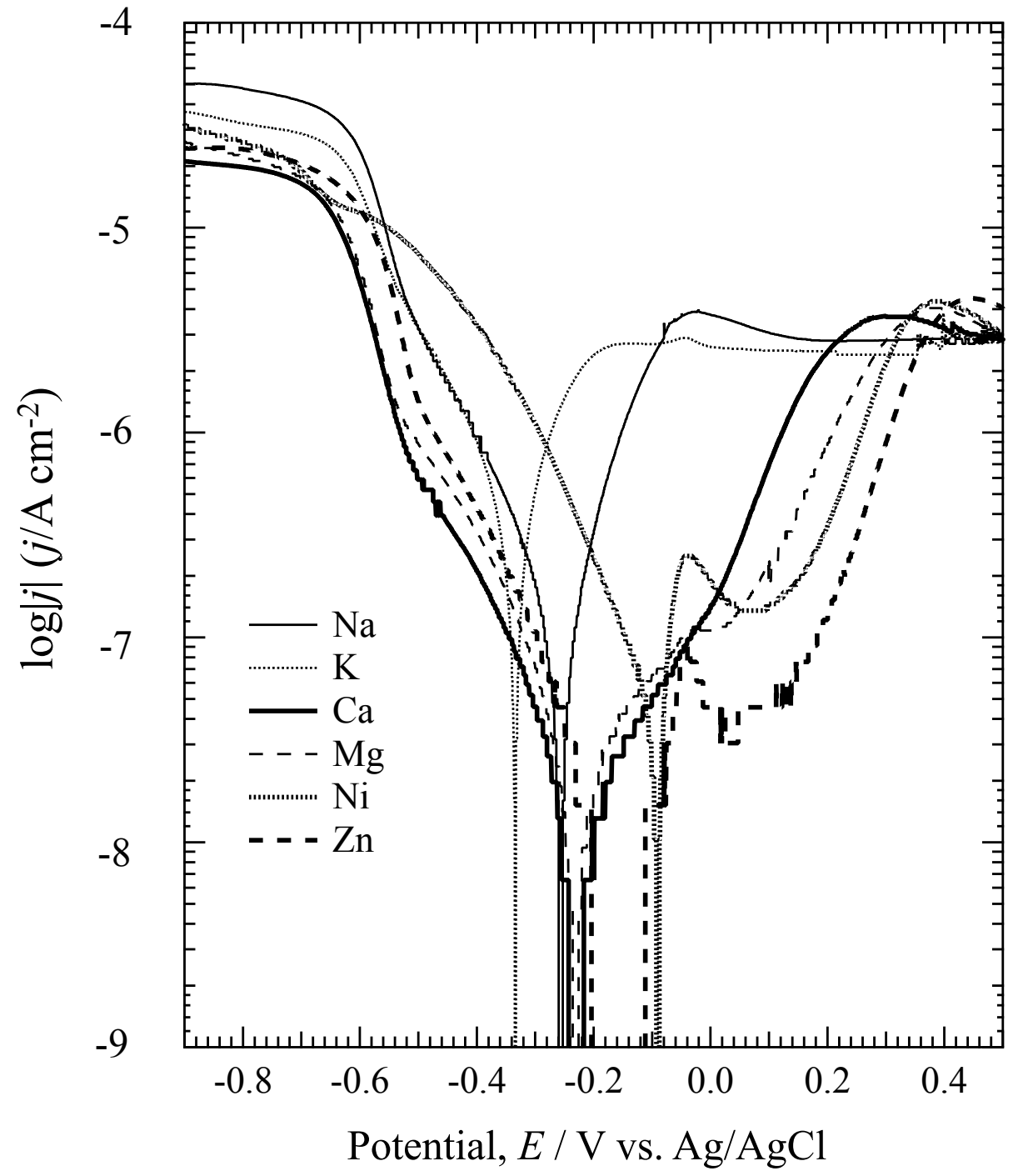

Figure 4 

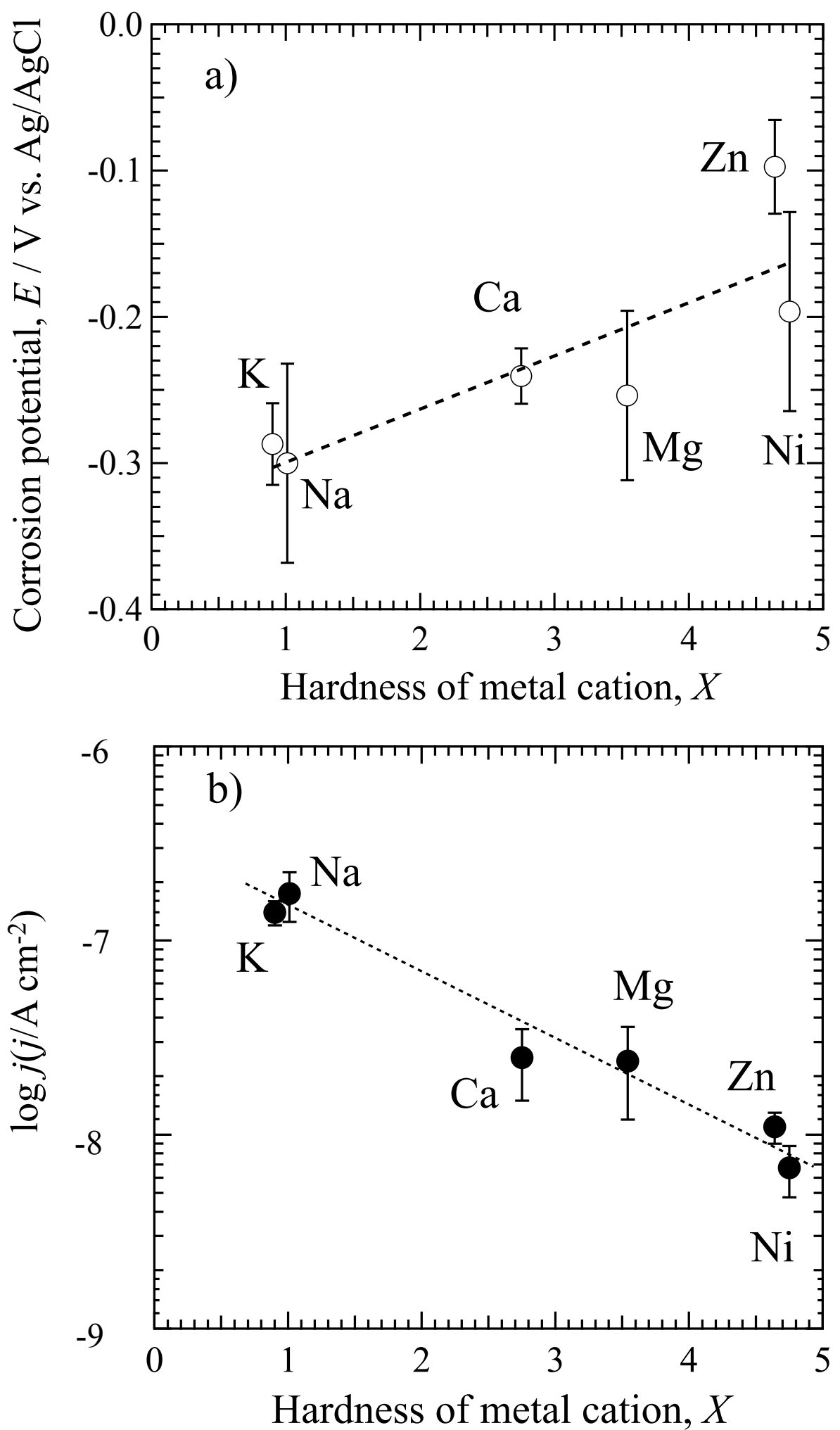

Figure 5 

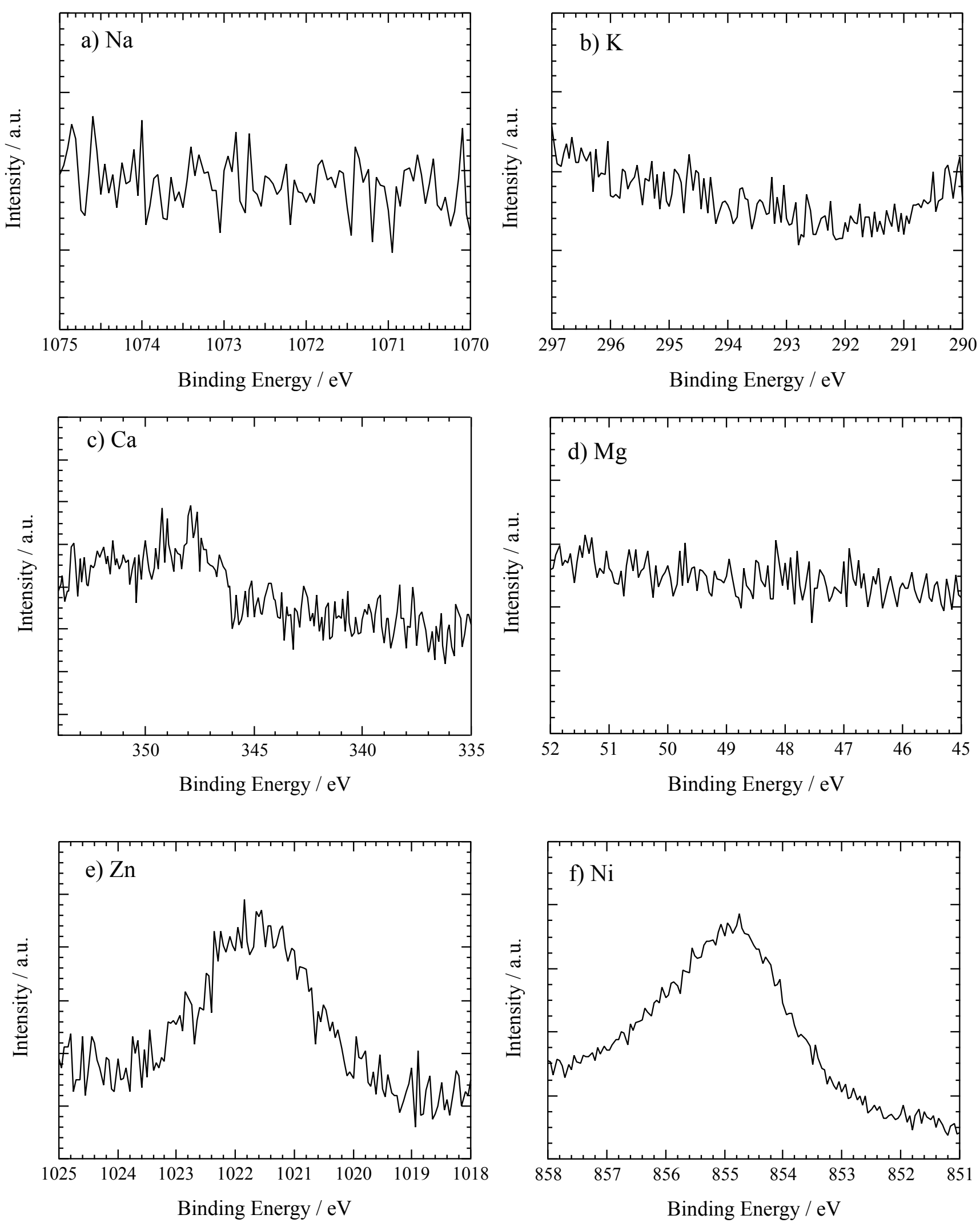

Figure 6 

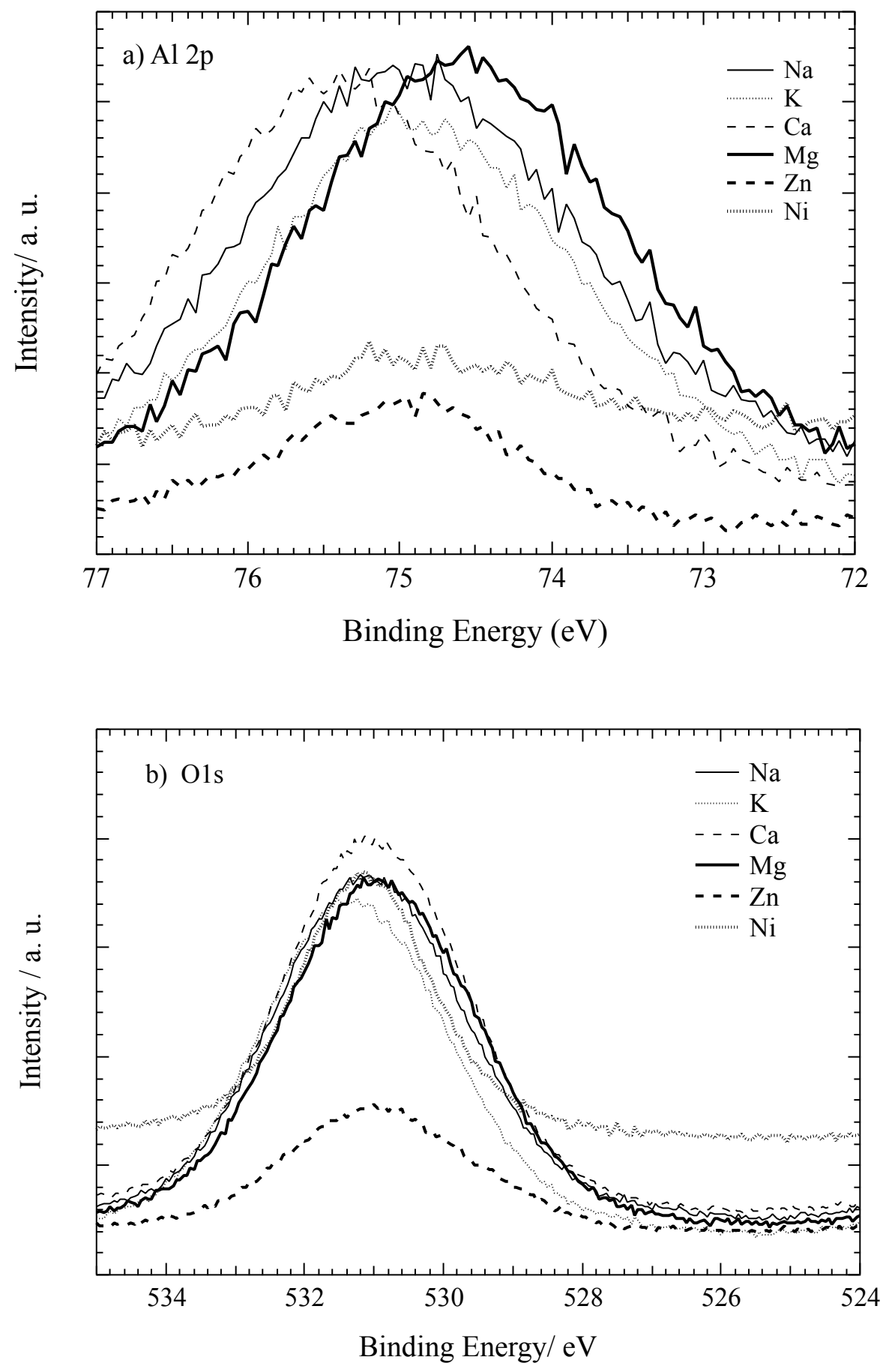

Figure 7 

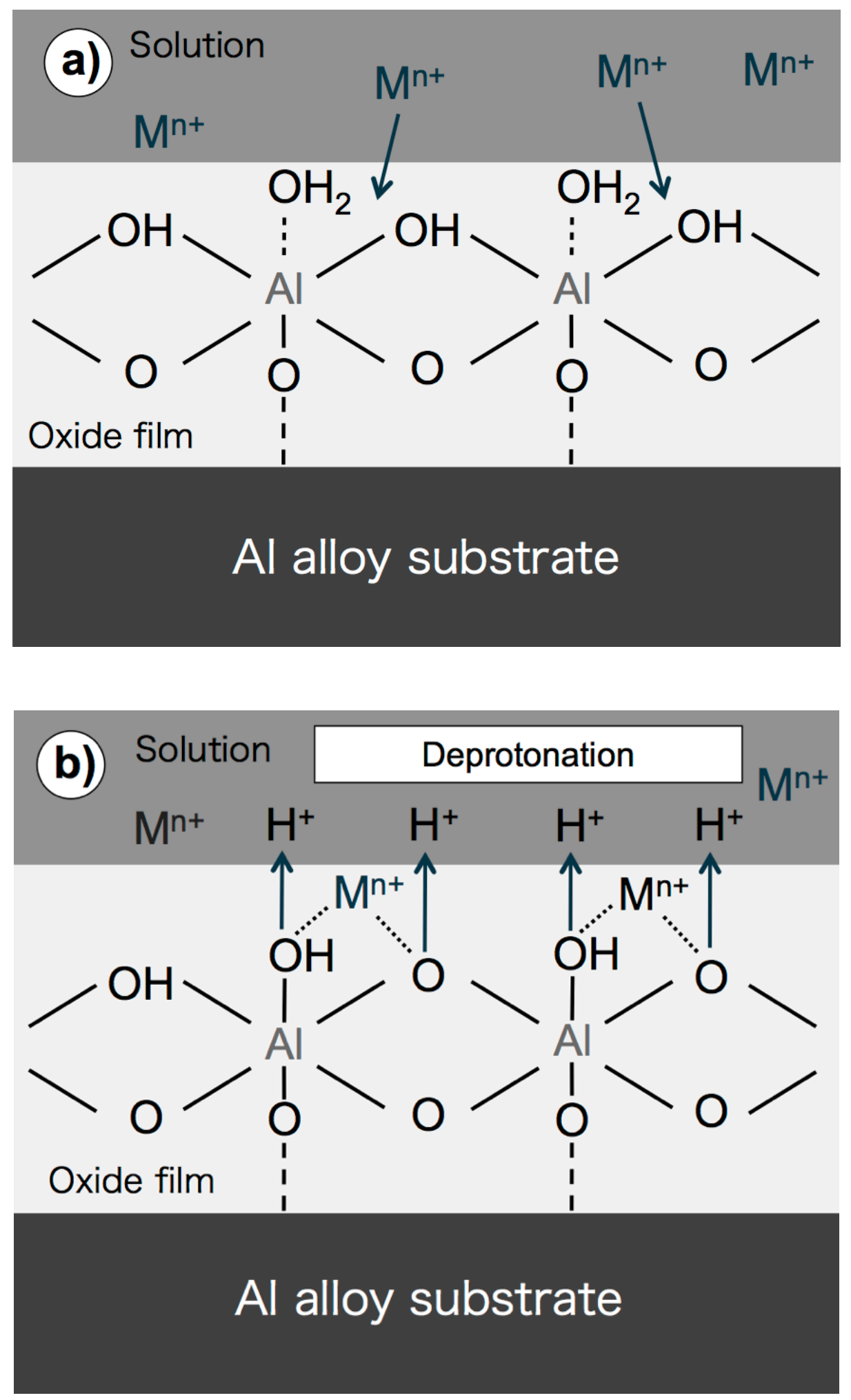

Figure 8 

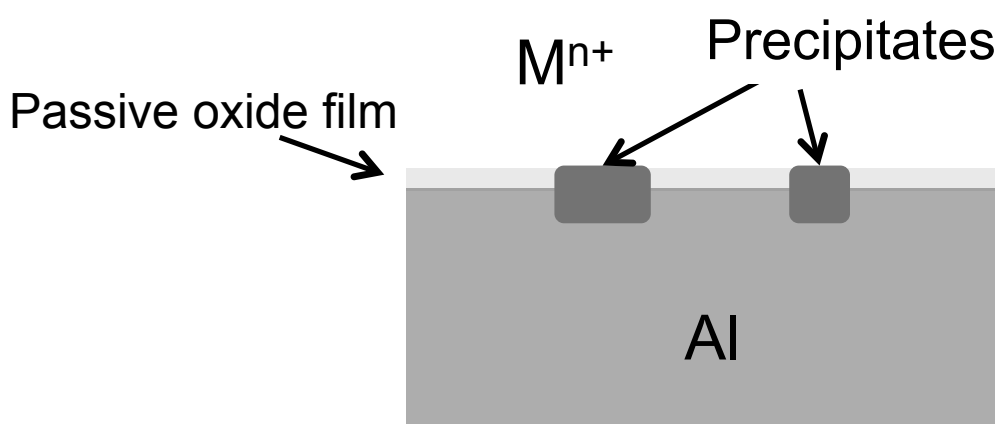

Soft metal cations

$\mathrm{K}, \mathrm{Na}, \mathrm{Ca}, \mathrm{Mg}$

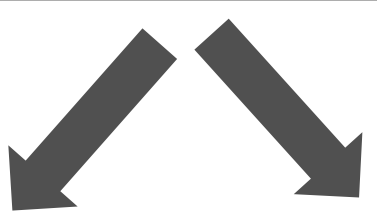

Hard metal cations $\mathrm{Zn}, \mathrm{Ni}$
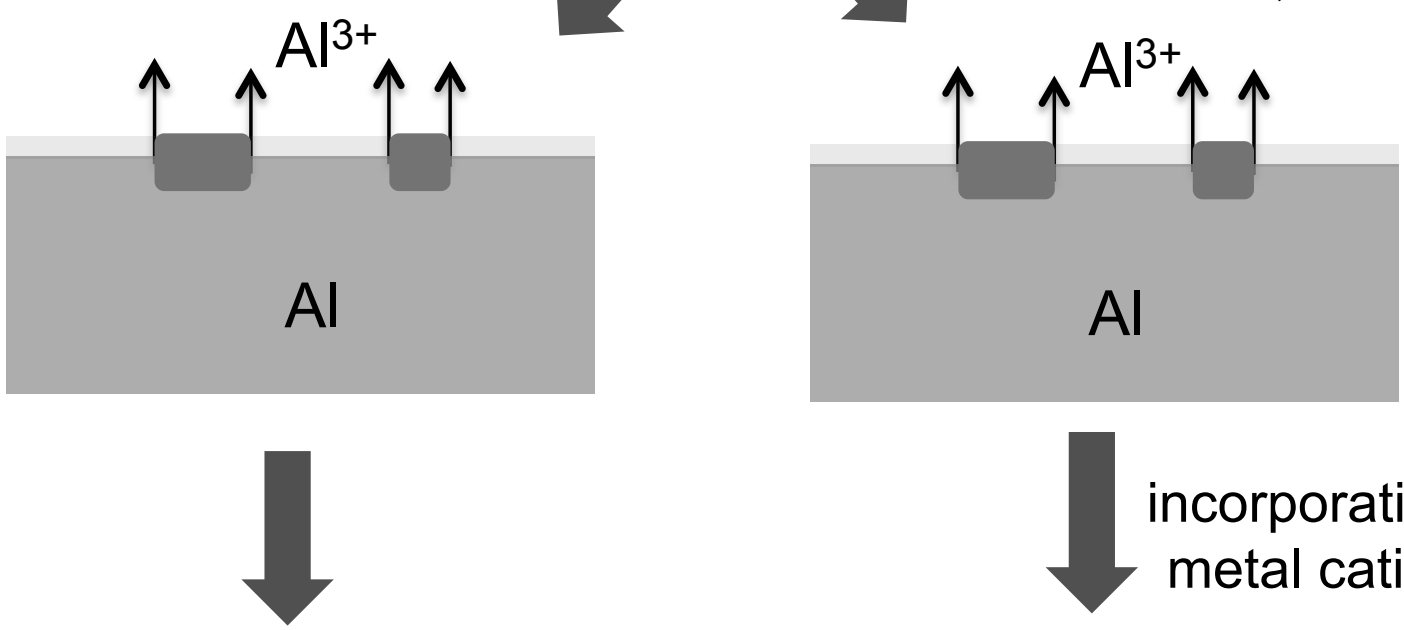
incorporation of metal cations
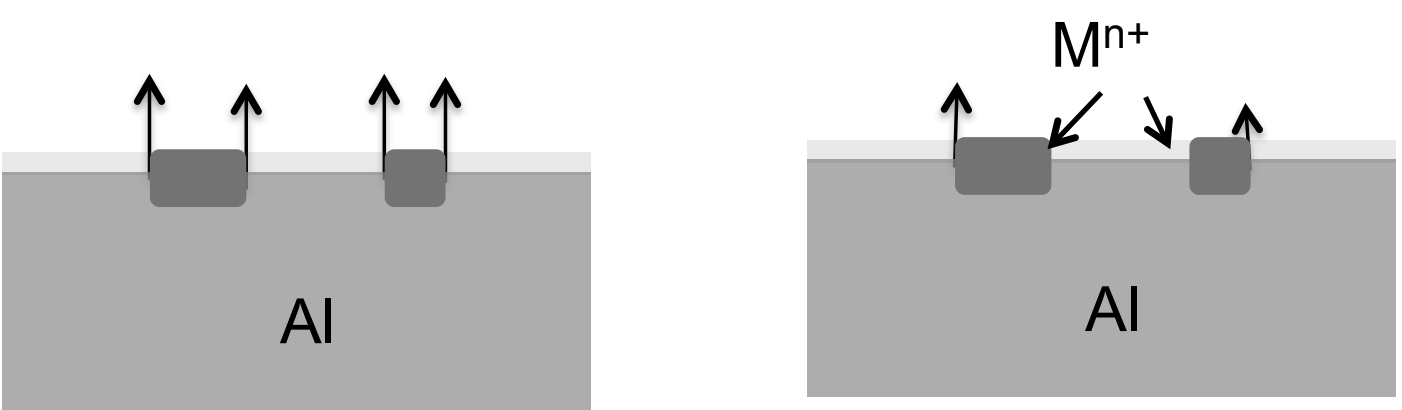

Figure 9 


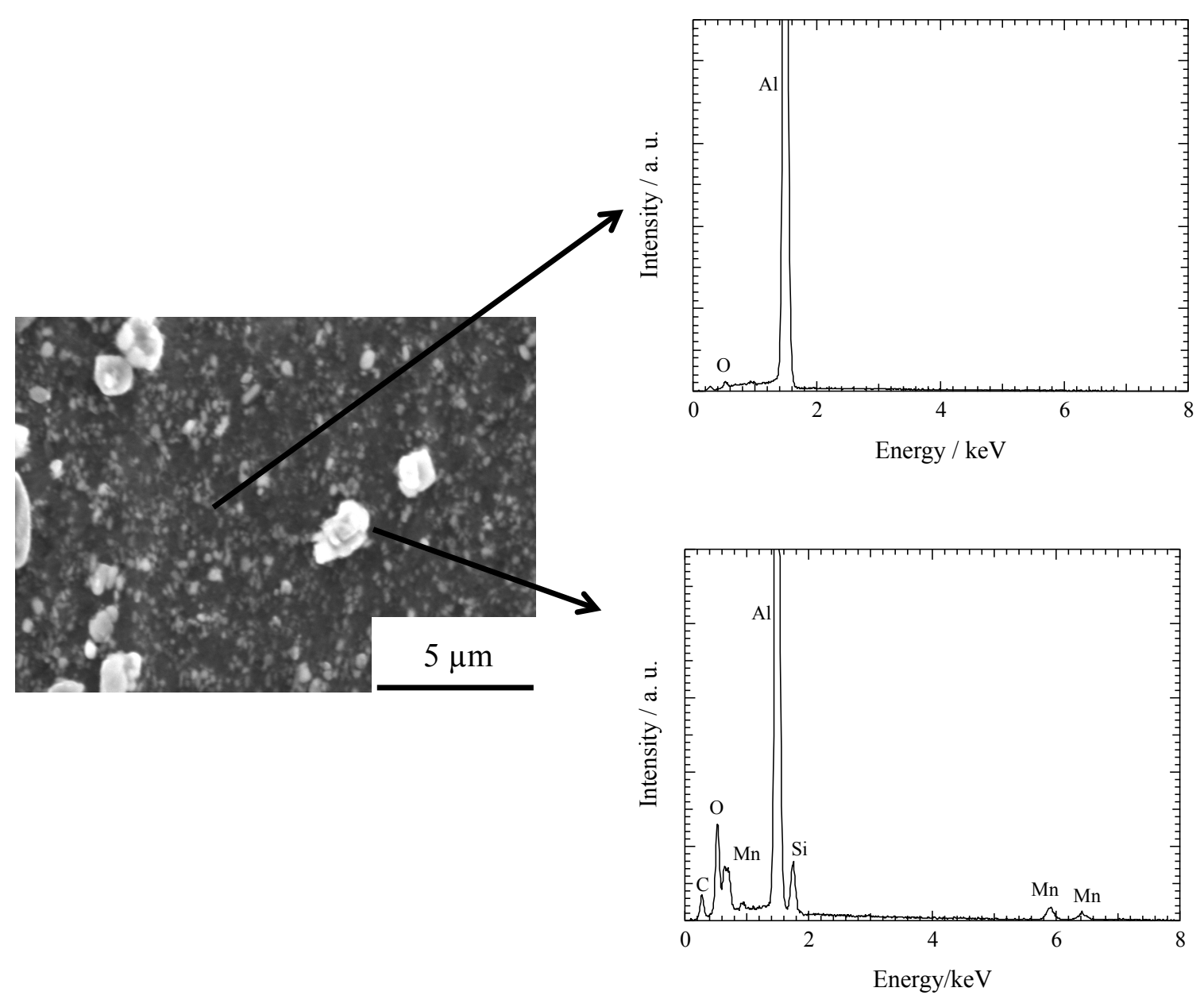

Figure 10 